\title{
Nigerian Legislature and Public Accountability in Presidential Democracy: An Overview
}

\author{
Dr. Ozy B. Orluwene, JP \\ Department of Political Science, Ignatius Ajuru (Rivers State) University of Education, \\ P.M.B. 5047 Port Harcourt, Nigeria \\ Email: ozywene@gmail.com
}

Doi:10.5901/mjss.2014.v5n27p1411

\section{Abstract}

This study is an overview of the legislature and public accountability in presidential democracy (presidentialism) in Nigeria. The doctrine of separation of powers has long recognized the legislature as one of the tripod or arm of government primarily responsible for law making as an antidote to abuse of powers and egregious violations of human rights. Consequently, as a fundamental key indicator and backbone of the health of presidentialism, the legislature is seriously viewed to the extent to which the principles of separation of powers are adhered to, its foothold established and alive as a mechanism through which the masses expresses their views and guarantee public accountability and transparency in governance. Unlike the Westminster (parliamentary model where it is (was) an appendage and extension of the executive arm of government). The study relied essentially on secondary data while personal observation was equally employed as methods of data generation. Based on the data collected and analyzed, the study argued that for accountability to be enhanced in governance there is the need for the legislature as the first estate of the realm to use the state apparatus to pursue public good as to enhance responsible and responsive government. This study recommends among others that public accountability enhancement measures should be emphasized and strengthened in the practice of presidentialism in Nigeria.

Keywords: Legislature, democracy, accountability, presidentialism, Westminster.

\section{Introduction}

Globally, the doctrine of separation of powers as a democratic norm has remained the hallmarks of presidentialism of which development and progressive activists are aware. The presidentialism conscious individuals are always crusading for the observance of the democratic tenets and norms of separation of powers. These proponents are watch dogs of democracy in countries where presidentialism is entrenched. That is why those that drafted the 1979 Constitution of Federal Republic of Nigeria (CFRN) as applicable in 1989 and 1999 respectively expressed fears that presidential process could easily be abused if the legislature is not vigilant and capable enough to act as a check. Indeed, a legislature that is composed of enlightened members should consciously be a check on the executive arm and not a mere rubber-stamp or stooge of the executive (Zimako, 2009:25).

Oftentimes, money rules the conscience of some members of the legislature not that they are not aware of the constitutional procedures, but they choose to remain indifferent. They are influenced with financial incentives by the executive to accept the actions of the executive, thus betraying what is considered the bond between them and the electorate on whose behalf they are in parliament. Thus in Nigeria generally, and the legislature in particular, the principles of accountability has been treated with levity, particularly by the law makers. And democracy as a concept preaches the rule of law, consequently, as part of rule of law; the president and the entire leadership are accountable to the people of Nigeria.

People have complained of crisis in virtually all aspect or sectors of the economy and many things crying for attention. Our battered national economy is certainly one of them...the grim conditions of many of our citizens was worsened by the deteriorations of public service where access to pipe-borne water and affordable healthcare became a dream and the supply of electricity became epileptic and unreliable in an era in which globalization has made such services ubiquitous and cheap (Obasanjo, 1999, Adegoroye, 2006 cited in Kwaghga, 2012).

Above all, as part of the complain of the Nigerian masses and the often declared reasons for military takeover are instructive and deserve to be taken seriously as part of levity in public accountability. Mismanagement of the economy and the consequent decline in living standard were cited as the central reasons of taking over: 
of food at reasonable prices for our people.[...] Health services are in shambles as our hospitals are reduced to mere consulting clinics, without drugs, water and equipment. Our educational system is deteriorating at an alarming rate. Unemployment figures... have reached embarrassing and unacceptable proportions. In some states, workers are being owed salary arrears of eight to twelve months and, in others, there are threats of salary cuts. Yet our leaders revel in squandermania, corruption and indiscipline [and] continue to proliferate public appointments in complete disregard of our stark economic realities (Excerpts from radio broadcast announcing the coup by Brigadier Sani Abacha, 31 December 1983 quoted in Osaghae, 2002:169).

With the principles of accountability, public officers especially the legislature are charged with the responsibility of using public resources (human and material) to obtain for the good of the public. In simple terms, the legislature should be compelled by public policy to explain how they managed state resources particularly where the people can feel, see or benefit from those services.

It is against this background that this study takes an overview of the legislature and public accountability in presidentialism in Nigeria to ascertain whether the legislature has been able to enhance public accountability.

To achieve the objective in this study, the study is divided into the following parts: part one - introduction; part twoconceptual clarifications; part three- constitutionalism and legislative accountability while part four is legislatures and public accountability, and part five is the concluding remarks.

\section{Conceptual Clarification}

\subsection{The Legislature}

For obvious reasons, the legislature is generally regarded as the sovereign organ of the state power. This first among the political trinity or the three arms of constitutional government may be defined as a body of persons in a country or a state vested with power to make, alter and repeal laws in the realm of representation and the site of sovereignty (Egwu, 2005:19). The legislature which is considered as being the representative of the people and thus acts as their agent is at the core of the liberal democratic tradition. To begin with, modern democracy, especially the liberal democratic type is about people exercising power through their elected representatives, therefore, does not only arise from the fact that its functions and tremendous roles are versatile, encapsulating executive and judicial functions; it is also the only expression of the popular view of the people. The roles and responsibilities of the legislature indeed, if extrapolate from the western democracies, where the creation of parliaments and constitution that became the foundations of the liberal state emerged from the struggles of the nobilities, the middle class, workers and peasants, a legislative assembly can be said to represent the illusory forms of the class struggles, providing a platform for contestations of several political forces and tendencies.

In fact, John Staurt Mill (1962) wrote in his representative democracy cited in (Lawan, 2009:151) "the legislative acts as the eyes, ears and the voice of the people". Consequently, the foremost characteristic of a legislature is its intrinsic link to the citizens of the state- representation. Mill further submits:

The proper office of a representative assembly is to watch and control the government: to throw the light of publicity on its acts, to compel a full exposition and justification of all of them which anyone considers questionable; to censure them if found condemnable... In addition to this, the parliament has office ... to be at once the nation's committee of grievances and its congress of opinions (Cited in Ornstein, 1992, Lawan, 2009:15).

Deriving from the above, the role and responsibilities of the legislature in Nigeria especially in this democratic dispensation is clearly and unambiguously stated in 1999 CFRN. Thus, section 4(1) of the Constitution provides thus: "The legislative powers of the Federal Republic of Nigeria (FRN) shall be vested in the National Assembly of the Federation which consists of the Senate and House of Representatives".

Similarly, section 4(2) of the same constitution provides that:

National Assembly shall have powers to make law for the peace, order and good governance of the federation or any part thereof with respect to any matter included in the exclusive legislature list set out in part I of the second schedule of this constitution.

Furthermore, 4(3) state that:

The power of the National Assembly to make laws for the peace, order and good governance of the federation with respect to any matter included in the exclusive list shall serve as otherwise provided in this constitution to be the exclusion of House of Assembly of States. 
While, section 4(6) of the said constitution vest the legislative powers of a State of the Federation in a House of Assembly of the state. However, the legislative powers of the state assemblies are much the same as those of National Assembly except that House of Assembly shall not make laws on any matter not included in the exclusive list. Despite being known the world over, primarily as law-making bodies, the institution also perform many other responsibilities and functions of watch dog, checkmate executive excesses and guarantee separation of powers in democracy.

However, it is obvious that the legislature represents the true bastion of democracy in most constitutional government because representation is greatly symbolized in the institution of legislature. That is why Oyovbaire emphasizes thus:

In democratic theory, the legislature is an institutionalized manifestation of the people's will or sovereignty. It is the major source of policies, rules and laws governing society and the primary arena for articulating and aggregating interests. The legislative processes involves, attracts and encompass, not only the duly accredited legislative actors, groups and interests such as, among other executive, judiciary and administrative agencies, political parties, sociocultural and religious pressure groups and lobbyists. The legislature consists normally, of a complex network of roles and interest of local, national and international actors and communities (Oyovbaire, 2001 cited in Lawan, 2009:151152).

One significant aspect of the legislature in Nigeria, however, is that it remains a weeping baby in its relationship with the executive arm of government. This probably derives from the episodic history of the legislature in Nigeria. In the colonial period, what then existed as the legislative council was not the organ of the colonized people in exercising power of influence. In the post independence period, the frequent interruptions of democracy experiments have not allowed for the growth and nurturing of the legislature. Thus, while the executive and judicial branches had always survived under the unitary command of military regimes, the legislature was sacked and the constitution suspended. The overall consequence of this is that the legislature remains an "underdeveloped" arm of the state (Egwu, 2005:19).

Therefore, democracy is strengthened or weakened through legislative activities. Legislation governs human conduct and places it within a specific frame of coexistence. Legislatures make law not only on human conduct but also for the societal wellbeing. Constitutions and legislation therefore control and fashion the political system. They determine the nature of the system which in turn dictates the viability. Thus Ibrahim cited in (Okolie, 2003) was right when he noted that the legislature is supposed be a powerful institution, the only power that can create other powers.

\subsection{Democracy}

To several authors, democracy is a relative and elusive concept. It meanings and application depends on how you look at it. Hence the concept of democracy has been subjected to infinite debate over the centuries. That was why De Jouvenel cited in (Olojede, 2006:275) put it thus: "our discussions about democracy, all argument whether for it or against it are stricken with the intellectual futility because the thing at issue is indefinite". And tyrants from Benito Mussolini, Stalin, Marcus Nguema, Samuel Doe, Sani Abacha among others had at different times alluded to their regimes as democratic. In spite of the differences in conceptualisation and practice of democracy, Osaghae cited in (Oyedele,2000:90) notes that all its versions whether liberal or capitalist, socialist and African brand, share the fundamental objective of "how to govern the society in such a way that power actually belongs to all the people.

Similarly Huntington quoting works of (Schumpeter cited in Ajibewa, 2006:264) describe democracy "as that institutional arrangement for arriving at political decisions in which individuals acquire powers to decide by means of a competitive struggle people's vote". The watch word is on competitive struggle which allows every individual of the state to participate in contesting and choosing who will represent him; this exclude the use of force or coercion through the state apparatus. Therefore, Huntington asserts that:

true democracy means liberty, equality, fraternity, effective citizenry control over policy, responsible and responsive government, honesty and openness in politics, informed and rational deliberation, equal participation and power and virtues.

No country has been able to achieve complete democratic system as stated above. This explains why Robert Dahl cited in (Igbokwe-lbeto and Akhakpe, 2012:238-239) came up with what he calls 'polyarchy'. Polyarchy according to Dahl are 'administrations that have been substantially popularised and liberalised that is highly inclusive and extensively open to public contestation'. The process of making polyarchies more democratic is referred to as democratisation.

Garreton (1995) therefore, see democratisation as the process of establishing, strengthening; extending the 
principles, mechanisms and institutions that define a democratic administration. Democratization involves a political system embracing mere political openings, the rules of law and constitutionalism in spheres of the political system.

Above all, Chafe (1994) contends that democracy means among others, the involvement of the people in the running of the political, socio-economic and cultural affairs of the society. Indeed, if democracy is government of people, by the people and for the people, its existence must be in an open polity that is responsible and accountable to the general citizenry.

\subsection{Accountability}

It is not a surprise that over the years there has emerged diverse definitions of the concept, therefore, no universally acceptable definition of accountability because it is a fundamental but underdeveloped concept in Public Administration (Zek and Dubnick cited in Ezeani, 2008:2). But the study adopts the conceptual clarification as stated in Orluwene(2013:280) thus:

Accountability requires prudent expenditure of money and the existence of appropriate fiscal records. In other words, Smarth and Haque cited in Ezeani (2003) opine that the principle of accountability specifically requires "that the government must have the assurance that the public funds are spent for the purpose specified and without personal gain to any private individual beyond fair compensation for his service". That was why Robertson (1993:3) typical definition of accountability as concerns the process by which those who exercise power, whether as governments, as elected representatives or as appointed officials must be able to show that they have exercised their powers and discharged their duties properly. Such a broad definition is necessary as the detailed nature of accountability varies greatly with form of government.

It is important to state that the concept of accountability as applied to modern government and public administration represents a basic democratic ideal. "It is linked to government obligation to some external force or an acceptable standard or conduct" (Abdulsalami, 1999:72). For the purpose of this study, public accountability is defined simply as answerability for one's action or behaviour before a person or group of person entitled to it. Both the government administrators and agencies are required to answer for their actions before a person or a group of persons. Public accountability is based on the premise that all public servants (i.e. lesser persons or authority) own and hold their positions and everything associated with these positions, as trust for the people, who are their masters (higher persons of authority). Those who are expected to render service must account to the people for their successes and failures, and those who are entrusted with the custody and disbursement of public funds must appropriately account to the people for their use (Akpan, 1982:43).

\section{Constitutionalism and Legislative Accountability}

In Nigeria and most democracies of the globe, the legislature is not only assigned the onerous task or function of law making for good governance and ensuring that such laws are satisfactorily executed, but is also assign the tasks of monitoring and/or checking the activities of the executive and being checked in turn as to enhancing accountability and good governance.

Thus, to achieve the aforementioned, the legislature are therefore expected to pursue and embrace equity with "clean unadulterated hand", as to guide against reckless, undue acquisition and personalisation of public wealth that informed section 52 of the 1999 CFRN. In fact, section 52(1) emphatically states thus:

Every member of the Senate or the House of Representatives shall, before taking his seat, declare his assets and liabilities as prescribed in this Constitution and subsequently take and subscribe the Oath of Allegiance and the oath of membership as prescribed in the Seventh Schedule to this Constitution before the President of the Senate or, as the case may be, the Speaker of the House of Representatives, but a member may before taking the oaths take part in the election of a President and a Deputy President of the Senate, as the case may be, or a Speaker and a Deputy Speaker of the House of Representatives.

While section 94(1 and 2) of the said constitution also mandate or made every member of the State House of Assembly. It therefore states as follows:

(1) Every person elected to a House of Assembly shall, before taking his seat in that House, declare his assets and liabilities in the manner prescribed in this Constitution and subsequently take and subscribe before the Speaker of the House, the Oath of Allegiance and oath of membership prescribed in the Seventh Schedule to this Constitution, but a member may, before taking the oaths, take part in the election of the Speaker and 
Deputy Speaker of the House of Assembly.

(2) The Speaker and Deputy Speaker of a House of Assembly shall declare their assets and liabilities in .the manner prescribed by this Constitution and subsequently take and subscribe the Oath of Allegiance and the oath of membership prescribed as aforesaid before the Clerk of the House of Assembly.

These sections, of the 1999 CFRN mandates the legislators of the Nigerian federation to live within their incomes, as approved and then concentrate on their legislative obligations. The legislators as representative of the people are expected to reflect, articulate, harmonize and propagate the choices, preferences and preferment of the people that elected them. The electorate, have the right to recall them whenever there is proven loss of confidence, thus, the legislators are under constant scrutiny.

In fact, sections 69(a) and 110(a) of 1999 CFRN respectively states as applicable how a member of Senate and House of Representatives (National Assembly) may be recalled:

(a) if there is presented to the Chairman of the Independent National Electoral Commission a petition in that behalf signed by more than one- half of the persons registered to vote in that member's constituency alleging their loss of confidence in that member; and

(b) the petition is thereafter, in a referendum conducted by the independent National Electoral Commission within ninety days of the date of receipt of the petition, approved by a simple majority of the votes of the persons registered to vote in that member's constituency.

And State House of Assembly thus:

(a) if there is presented to the Chairman of the Independent National Electoral Commission a petition in that behalf signed by more than one- half of the persons registered to vote in that members' constituency alleging their loss of confidence in that member; and

(b) the petition is thereafter, in a referendum conducted by the Independent National Electoral Commission within ninety days of the date of the receipt of the petition, approved by a simple majority of the votes of the persons registered to vote in that member's constituency.

The constitutionality of the above provisions boils down to public accountability and a good responsive representation in that, the legislators are constantly hard pressed to discharge their legislative function in line with the demand, expectation and desires of the electorates.

The legislature being the eyes, ears and the voice of the people is intrinsically linked to the masses as the custodians of the peoples diversified aspirations and desires. It ensures that public wealth is used for public interest. This is why Sections 80-84 of the aforesaid 1999 CFRN largely assigned the powers and control over public funds to the legislature.

Thus, Sections 80-84 and 120-124 of the said constitution basically reside such powers to both the National Assembly and States House of Assembly to oversee and regulate the executive on public spending respectively.

Furthermore, Sections 88 and 128 of the aforesaid constitution of Nigeria respectively reside on the legislative at the National Assembly and State Assembly, the power to conduct investigation. Section 88 stipulates thus: Subject to the provision of the constitution, each House of National Assembly shall have power by resolution publish in its journal or in the official gazette of the government of the Federation to direct or cause to be directed an investigation into:

(a) any matter or thing with respect to which it has power to make laws; and (b) the conduct of affairs of any person, authority, Ministry or government department charged, or intended to be charged, with the duty of or responsibility for: (i) executing or administering laws enacted by the National Assembly, and (ii) disbursing or administering moneys appropriated or to be appropriated by the National Assembly.

While section 128 which is applicable to the State, states thus: Subject to the provisions of this Constitution. a House of Assembly shall have power by resolution published in its journal or in the official gazette of the Government of the State to direct or cause to be directed inquiry or investigation into:

(a) any matter or thing with respect to which it has power to make laws ; and (b) the conduct of affairs of any person, authority. Ministry or government department charged, or intended to be charged, with the duty of or responsibility for:

(i) executing or administering laws enacted by that House of Assembly, and (ii) disbursing or administering moneys appropriated or to be appropriated by such House.

In addition, section (2b) states that: the powers conferred on the National Assembly/State Assembly under the provisions of these sections are exercisable only for the purpose of enabling it to:

(b) expose corruption, inefficiency or waste in the execution or administration of laws within its legislative competence and in the, disbursement or' administration of funds appropriated by it.

The 1999 CFRN provides in Sections 89 and 129 respectively the procedures for the National Assembly and State 
House of Assembly to actualise accountability and good governance. However, as emphasised above, the legislature are themselves expected to exhibit transparency and responsiveness in the discharge of their legislative functions. Regrettably, the legislators are themselves placing higher premium of personal and pecuniary interests at the expense of the public interest. Thus, they emerged financial recklessness as corruption and intense insatiability have rather eaten deep into their psyche and hence eroded and/or vitiate their legitimacy (Okolie, 2003).

\title{
4. Legislatures and Public Accountability
}

The practice of presidentialism in Nigeria started with Second Republic in 1979 after a protracted military rule. For almost one year of their resumption, the legislatures concerned itself with issues of accommodation, comfort and salaries of its members. On the very day the Nigerian legislature resumed duty, the members passed a motion requesting for one thousand $(\mathrm{N} 1,000)$ Naira salary advance pending the determination of their salary. Special free transport facilities, immunity from the odd-even number motor traffic law of Lagos, and alternative accommodation at Victoria Island instead of the Badagry high-rise apartments reserved for the Law makers (The Punch October, 1979 cited in Adebo, 1988:90).

The Nigerian legislature pressed for these self-seeking demands for special accommodation despite public reactions as regards the Badagry high-rise apartment. The Punch Newspaper of November 13, 1979 (cited in Adebo, 1988:91) observed thus:

\begin{abstract}
For sheer luxury and grandeur the apartment for members of the national assembly along Badagry road will beat any five Star Hotel in the country hands down, and will rival any high-rise apartment any where in the world... In terms of furnishing it will rival those 30,000 houses at Victoria Island. Every item of furniture was imported. The kitchenette is equipped to the teeth, right up to teaspoons.
\end{abstract}

In spite of this luxury and grandeur, the members of the legislature rejected it and threatened to boycott sitting indefinitely if the proposed civil servant high-rise apartment in the exclusive Victoria Island, which they preferred was not allocated to them immediately.

Ultimately, the President bowed to this "white mail" and ordered that the Victoria Island apartment be transferred to the legislators. When the members of the legislature were to leave the Badagry apartment, they carried away public furniture and utensils they rejected as unfit for" Honourable Members" to their private homes. Indeed, when the demand was not only for fee and posh accommodation, the law makers also ganged up to fix their own salaries and allowances that were huge. Yet majority of the population live in rural areas and in abject poverty and where the provisions of essential services are grossly inadequate.

At this time too, the salaries of workers in many of the states of federation were not being paid for months. For a group of people "elected or selected" to represent and protect the interest of the nation to appropriate this huge chunk of the nation wealth to themselves through fat salaries and fringe benefits was a sheer insensitivity to the grim socioeconomic condition in the country and indeed an abuse of the legislator's oath of office. This abuse of power was arrogantly displayed when, in reaction to public outcry against the fat salaries and fringe benefits, the law makers boasted that "they have the power to make law and we have made it" (Adebo, 1988:93).

The Senate in the Fourth Republic of Nigeria presidentialism was embroiled in allegation of corruption immediately after the inauguration and swearing in ceremony in June 1999. The senators purportedly received eight hundred and fifty thousand $(\mathrm{N} 850,000)$ Naira each to vote Evans Enwerem instead of Chuba Okadigbo as Senate President and collected five million (N5m) Naira each as furniture allowance as against the three million, five hundred thousand (N3.5m) Naira they declared to the public (Ologbenla, 2007, Aliu, 2013).

The controversy surrounding the furniture allowance further dampened the enthusiasm of the Nigerian public. Many Nigerian were of the opinion that given the depressed state of the Nigerian economy, furniture allowances of five and three million Naira to each of the members of the senate and house of representative respectively shows the level of insensitivity of the legislators.

Consequently, another major embarrassment that confronted the nation legislature was that the leadership of the senate has not been exempted from the corruption scandals. The trio, Senators Evans Enwerem, Chuba Okadigbo and Adolphus Wagbara were impeached as Senate President, for forgery, perjury, corruption, mismanagement of public funds and lack of public accountability. Chief Evans Enwerem, was accused of perjury. It was alleged that Evans Enwerem was jailed in 1945 for stealing from public treasury. In fact, he was allegedly jailed for embezzling money when he was a revenue clerk of the Regional government of Eastern Nigeria. He was similarly accused of false declaration of age. 
It was discovered by the Tell Magazine of August 9, 1999:17 that in 1983, when Evans Enwerem was appointed the National Party of Nigeria (NPN) Liaison officer for Imo State, Enwerem declared his age was 58. But eight years later when he became the governor of Imo State in 1991, his curriculum vitae showed that he was born in 1935, which would have made him 56 at the time he was elected. This discrepancy in age raised doubts about the integrity and credibility of the Senate President. He was similarly discovered to have been involved in financial impropriety and abuse of office. As a governor, he was alleged to have used his position to secure for his company, Wentfort Investment Limited, a property jointly owned by governments of the then four Eastern States as at 1993. Datec International Nigeria Ltd had been granted a twenty-year lease for the same property since 1985, and the company had in April, 1993, offered to purchase the same property (the unexpired residue) for twenty three million, four hundred thousand $(\mathrm{N} 23,400,000)$ Naira. Enwerem's company because of his influence as the then governor, beat them and purchased the already leased property for eighteen million, six hundred thousand (N18, 600,000) Naira (Tell Magazine cited in Lawan, 2009:159). Above all, he was also allegedly indicted for financial impropriety when he was on the board of the Nigerian Airway Authority (NAA), during the Second Republic. It is clear from Enwerem's travails that "his past rose up to destroy him", as he was compelled to resign as the Senate President.

Senator Chuba Okadigbo was found guilty of inflating the cost of contracts and other sundry acts. As the Clerk of the National Assembly disclosed before Kuta led Adhoc committee which was set-up to investigate the massive and monumental scandal that characterized the Okadigbo leadership of the senate. According to the Clerk, the Senate leadership re-awarded a fifty five ((N55m) million Naira contract for one hundred and seventy five (N175m) million Naira. He disclosed then that some of the disbursements for the contract were approved and released in breach of basic financial regulations. He further alleged that the Senate President Chuba Okadigbo approved for himself thirty seven million (N37m) Naira as furniture allowance instead of the twenty five million (N25m) Naira approved for it. Thirty million $(\mathrm{N} 30 \mathrm{~m})$ naira for extra vehicles apart from the official cars worth thirteen (N13) million naira for his Lagos residence alone, twenty five (N25m) million Naira for office (Ojakaminor, 2004:247, Lawan, 2009:160).

In fact, the sum of N175 million that went to the Senate president was for the street lighting of a one-kilometer stretch of road from the Eagles Square to the National Assembly. And as the Idris Kuta Panel later revealed in its final report, the National Assembly had become a place where people could make money without doing anything. This is in reference to the mind-boggling financial scandal that became apparent especially under the ignominious Okadigbo leadership (Lawan, 2009:160).

While Senator Wagbara was indicted for collecting fifty five (N55m) million Naira bribe from former Minister of Education Prof. Fabian Osuji to get Senate to facilitate easy approval of inflated budget of the Ministry in 2005 (Ogundiya, 2009, Lawan, 2009, Aliu, 2013). In fact, from the investigations by the Economic and Financial Crime Commission (EFCC), the Senate and House Committees on Education demanded a bribe from the Minister of Education before they grant him audience to defend his ministry's 2005 budget proposal. Consequently, the National Universities Commission (NUC), a parastatal under the ministry agreed to give a loan of twenty (N2Om) million Naira while the ministry sources the balance of thirty-five (N35m) million Naira. The money was in fact delivered later to the house of Senator Adighige at Apo legislative quarters in the company of the Minister of Education (The Source Magazine cited in Lawan, 2009:162).

In the final analysis, the minister was sacked and the Senate President Adolphus Wagbara was forced to resign after denial and counter denial by the minister and the law makers. The senators and the honourable members of the house were similarly and also stripped of their respective chairmanship positions of the committees in the two chambers. Thus, both Dr. Garba Matazu and Senator Ibrahim Abdulazeez resigned the chair of their respective committees.

Similarly, Senator lyabo Obasanjo-Bello who is the daughter of former President Olusegun Obasanjo, as Chairman of Senate Committee on Health in 2008 was arrested, interrogated and arraigned in court by EFCC for receiving ten $(\mathrm{N} 10 \mathrm{~m})$ million Naira bribe as her own share of the committee largesse from the unspent budget of 2007 (Alabi, Olujinmi and Fashagba, 2010, Aliu, 2013).

Another dimension of the level of accountability that permeates through the senate of the Fourth Republic presidential democracy is the inflation of prices of cars from three million, five hundred (N3.5m) Naira to about five million, one hundred (N5.1m) Naira each, which all the senators collected. They shared three hundred and nineteen (N319m) million Naira through award of contracts to ghost firms (their cronies) in contravention of their jurisdiction rights, and Okadigbo also received twenty two (N22m) million Naira as Christmas and Sallah welfare. It was reported that the Senators lacked shame and regards for accountability defrauded the National Assembly the sum of three hundred and seventy six (N376m) million Naira. The money was collected to settle the salaries and allowances of non-existent personal aids as each member was officially entitled to eleven (11) aids. Such was an extent of lack of accountability among the leaders who were supposed to be custodian of the nation's patriotic values (Akinbi, 2013:309).

Besides, senators are alleged to demand bribe before confirming political appointees or through what Tell 
Magazine of May 22, 2000:22 refers to as "arrangee approval". For instance, the former minister of Federal Capital Territory, Abuja, Mallam Nasir El-Rufai alleged/claimed that Senators Nasiru Ibrahim Mantu and Jonathan Zwingina demanded fifty four (N54m) million naira bribe from him (El-Rufai) before he could be considered for ministerial appointment. Though both Mantu and Zwingina denied the allegations, many Nigerians could not believe them because of the lack of accountability precedence set in the legislature (Ologbenla, 2007, Lawan, 2009:161).

The House of Representatives has its own share of the lack of shame and accountability and graft scandals that have rocked the legislature. Few months after the inauguration of the National Assembly of the Fourth Republic, the nation was embarrassed with cases of certificate scandals especially leadership of lower chamber of the National Assembly. Soon after Ibrahim Salisu Buhari was elected speaker, it became public that he had a case of perjury to answer, having made false claims regarding his age and degree certificates. In his submission to Independent National Electoral Commission (INEC), Buhari claimed he obtained a degree certificate from the University of Toronto in Canada. Similarly, he inflated his age from 29 to 36 , in order for him to satisfy the constitutional provision to contest the election to the honourable house. As a result, Salisu Buhari lost both his position as speaker and membership of the house (Egwu, 2005:27, Lawan, 2009:158). But the irony of whole drama was that the then President Olusegun Obasanjo later granted him reprieve and pardon. And it became obvious; the Buhari episode was a mere tip of the ice berg as the two chambers of the legislative house had a number of people who had had similar credibility problem.

Besides, the successor to Salisu Buhari as a speaker of House of Representatives Alhaji Ghali Na' Abba and his cohorts were also a squandermania of public funds. The House treasury was looted under all kinds of guise, particularly through contingency vote commonly called "The Pool". At least, seven hundred (N700m) million naira was dedicated to the pool for 2002 alone, while it also got handsome sums of the previous two years. The speaker disbursed the funds at his whims and caprices through his "free funds" and other spurious sub-heads, Na' Abba pampered his supporters in the house through huge sums of money approved to them as patronage (Oshunkeye and Bakare, 2002).

For instance, Tell Magazine investigation as cited in Akinbi (2013:309) revealed that through payment vouchers dated 13 and 15 March, 2002 respectively, one Sani Udu, Chairman House Committee on Education draw N13,246,533 to treat purported renal dysfunction at a London hospital. Also Shetima Shehu, as Na' Abba acolyte, got a total of $\mathrm{N} 3,542,231$ as refund for the treatment in 2001 of his wife's chronic pelvic inflammatory disease through vouchers dated 5 March, 2002.

Equally, Ibrahim G. Abubakar, Deputy Chairman, House Committee on Communication got one million four hundred and fifty thousand (N1.450m) Naira as refund for "out of pocket expenses" for the treatment of his wife in a London hospital months after delivery a baby girl through caesarean section in Nigeria. The payment was made through a voucher dated 10 January, 2002; while another lump sum of N3,128,000 was approved for him by Na' Abba for the wife to keep an 8th February, 2002 appointment with a doctors in Saudi Arabia. The systematic looting of the House of Representatives by certain members exposed the sleazy side of the "contract" which the speaker and his leadership cohorts signed with Nigerians (Akinbi, 2013).

Particularly, Mrs. Patricia Etteh, the first woman to be elected speaker of House of Representatives in Nigeria was forced to resign from the office of the speaker on the account of her indictment for misappropriating five (N5m) million dollars while Honourable Dimeji Bankole, the successor to Mrs. Etteh as the speaker is undergoing prosecution for the alleged eight hundred and ninety four (N894m) million Naira fraud committed while in office, having been investigated, arrested, interrogated and arraigned by EFCC (Ogundiya, 2008, Aliu, 2013).

Indeed, many more law makers in the lower chambers of the National Assembly have been accused accepting gratification in the course of performing their oversight functions. For instance, Ndidi Elumelu, Paulinus Igwe and Mohammed Jibo, all honourable members of House of Representatives were investigated, arrested, interrogated and arraigned in court by EFCC for their alleged involvement in five billion, two hundred (N5.2b) billion Naira power contract while serving as Chairman and members of House of Representatives Adhoc committee investigating the low/poor performance of the power sector (rural electrification) despite the huge investment in the sector (Alabi, Olujinmi and Fashagba, 2010, Aliu, 2013). Similarly, Honourable Herman Hembe and three other honourable members of the House of Representatives were accused of demanding gratification from Mss. Arumah Oteh, the Director General of Security and Exchange Commission (SEC) during the probe of the activities of SEC to give her and the organization a clean bill of health (Punch Newspaper, 2012 cited in Aliu, 2013).

Equally, Honourable Farouk Lawan who chaired the House of Representatives Adhoc Committee that investigated the subsidy scam was also investigated, arrested, interrogated and detained by the Nigeria Police on the allegation that he demanded and collected/receiving part payment of three $(\$ 3 \mathrm{~m})$ dollars bribe from a business man Mr. Femi Otedola to give his company a soft-landing. The law maker has since been charged and arraigned in court for fraud and corruption (Punch Newspaper, 16 ${ }^{\text {th }}$ June, 2012). 
From the foregoing analysis, it could be seen that Nigerian public officers- the legislatures that are charged to use public resources (human and material) to obtain good for the public has regrettably soil their hands hence obstructed from pursuing equity and accountability; therefore, placing higher premium of personal and pecuniary interests at the expense of the public interest hence making the actualization of accountability and good governance a difficult task in Nigeria presidential democracy.

\section{Concluding Remarks}

We have argued aptly and empirically demonstrated in this study that in Nigeria where presidential democracy is currently practiced, public accountability and separation of powers are all illusive, superficial and pejorative. It does not necessarily make for checks and balances. In fact, we noted that the legislators are compelled by both national and man-made factors to acquiesce to the manipulations, and dictates of the dominant actors whose predatory instincts taints and condition the legislative process instead of being best suited to promoting good and transparent governance in democratic society.

Hence, the legislature largely become mere mechanism for articulating and enforcing the interest of the few, over and above the interest of the majority thus antithesis to public interest and public accountability. Given the above scenario, the legislature will remain hapless, helpless, and dependent in so far as it allows the legislative chambers to swim and bath in corruption water that flows from the system.

For a high subservient, corrupt and inept legislature is bound to impinge on public accountability and undermine popular representation, participation and quality of legislation, as transparency is largely separated from governance and public accountability has regrettably become a mirage. The legitimacy crisis of the legislature has deepened as the need saddled citizenry has resigned themselves to fate.

The neutrality of the Nigerian state is in doubt as political stability is hanging in symphony. Public accountability will remain illusive and Nigerians will have to wait endlessly for the messiah who is not from the descendant of corrupt and visionless leadership.

We therefore suggest measure to tackle corruption which is multi-dimensional that involves the abuse of trust, processes and institution and not only money. Our anti-corruption agencies must be seen to be ready for the task and not as an instrument of political victimization as was in the past but guided strictly by law.

They should concentrate on the preventive measures by establishing and using appropriate mechanism for checking it as to reduce the number and cost of prosecution. The anti-graft laws should be amended to give the anticorruption agencies enough teeth to bite by establishing special court to try corruption cases.

All corruption cases should be made a capital offence to carry capital punishment like in murder, armed robbery among other heinous crime. It should not be made a bail able offence and the onus of prof should be left with the accused and not the accuser.

Similarly any member of the legislature accuse of corruption should be made vacate his seat pending when he clears himself of the allegation and there should be a provision in the constitutional amendment for his immediate recall of a legislature or suspension just as the judges are suspended by the National Judicial Council whenever there is a serious allegation against any judge.

The society needs ethical re-orientation and rebranding and the crusade must start from the top and within the government in practical terms, and finally made part of study curriculum in our educational system.

\section{References}

Abdulsalami, A. (1988) Accountability and policy making in local government system. In I.N. Obasi and N.O. Yaqub (eds) Local government policy making and execution in Nigeria. Ibadan: Sam bookman Publishers.

Adebo, A. (1988( "The legislature: overview and performance" in V. Ayeni and K. Soremekun (eds) Nigeria's second republic. Lagos: Daily Times Publications.

Ajibewa, A. (2006) "Democracy and corruption in Nigeria" in E.O. Ojo (ed) Challenges of sustainable democracy in Nigeria. Ibadan: John Archers Publishers Ltd.

Akinbi, J.O. (2013) "Corruption and governance in Nigeria, 1999-2005: A retrospective examination" in B. Sofela, V.O. Edo and R.O. Olaniyi (eds) Nigeria at 50: Politics, society and development. Ibadan: John Archers Publishers Ltd.

Akpan, N.U. (1982) Public administration in Nigeria. Lagos: Longman Nigeria Ltd.

Alabi, M. Olujinmi, A. and Fashagba, J.Y. (2010) The legislature and anti-corruption crusade under the fourth republic of Nigeria: constitutional imperatives and practical realities. International Journal of Politics and Good Governance 1 (1.2) quarter II.

Aliu, M. (2013) "Legislative corruption and democratic consolidation in the Nigerian Fourth Republic". Journal of Sustainable 
Development in Africa 15 (6). P. 106.

Chafe, K.S. (1994) "The problem of African democracy: Experience from the political transition in Nigeria". Africa Zamani No. 2.

Egwu, S.G. (2005) "The legislature in Nigeria's fourth republic" in A.A. Gana and Y.B.C. Omelle (eds) Democratic rebirth in Nigeria Vol. 1 (199-2003). Abuja: Afrigov.

Ezeani, E.O. (2003) Public accountability: A conceptual analysis, In E.O. Ezeani (ed) Public accountability in Nigeria: perspective and issues. Enugu: Academic Publishing Coy.

Igbokwe-Ibeto, C.J. and Akhakpe, I.A. (2012) "Culture, democracy and governance in Nigeria" in I.O. Albert (ed) A history of social conflict and conflict management in Nigeria. Ibadan: Peace and Conflict Studies Programme/John Archers Publishers Ltd.

Kwaghga, B. (2012) "Accountability and transparency in legislative process in Nigeria: A challenge" in Journal of Law, Policy and Globalization, 3.

Lawan, M.M. (2009) "Corruption and the national assembly: Subverting democracy in the Fourth Republic, 1999-2007" in A.M. Jega, H. Wakili and I.M. Zango (eds) Consolidation of democracy in Nigeria: Challenges and prospects. Kano: AKCDRT.

Ogundiya, I.S. (2009) "Political corruption in Nigeria: theoretical perspectives and some explanations". Anthropologist, 11(4).

Ojakaminor, E. (2004) Nigeria's Ghana must go republic. Happenings, Ogun State: the Ambassador Publications.

Okolie, A.M. (2003) "The legislatures and public accountability in Nigeria" in E.O. Ezeani (ed) Public accountability in Nigeria. Enugu: Academic Publishing Company.

Olajede, I. (2006) "Democracy and corruption: executive-legislative relationship in Nigeria's Fourth Republic" in E.O. Ojo (ed) Challenges of sustainable democracy in Nigeria. Ibadan: John Archers Publishers Ltd.

Ologbenla, D.K. (2007) "Leadership, governance and corruption in Nigeria" Journal of Sustainable Development in Africa, 9(3).

Ornstein, N. (1992), "The role of legislature in democracy". The Freedom paper series. California: Institute of Contemporary Studies (ICS).

Orluwene,O.B.(2013) "Public accountability and moral ethics :the quest for Niger Delta development" International journal of trade and commerce 2(2) pp278-289.

Osaghae, E.E. (2002) Crippled giant: Nigeria since independence. Ibadan: John Archers Publishers Ltd.

Oshunkeye, S. and B. Bakare (2002) "A house that stinks" Tell Magazine (Lagos) No. 19, May 13, 24-31.

Oyedele, S.O. (2006) "Bureaucracy and democracy" in E.O. Ojo (ed) Challenges of sustainable democracy in Nigeria. Ibadan: John Archers Publishers Ltd.

Robertson, D. (1993) Dictionary of politics. London: Europe Publication Ltd.

Zimako, O.Z. (2009) Face of a nation: Democracy in Nigeria, foreign policy and national image. India: Modern Approach. 